\title{
Ruminations on Union Organizing in the Private Sector
}

\author{
Julius G. Getman $\dagger$
}

The labor movement in the United States is in trouble. This fact is now widely accepted even by leaders of the AFL-CIO. It is also generally agreed that loss of membership and failure to organize are the most powerful indications of the movement's decline. One of the few bright spots from the perspective of a union supporter is that labor seems finally to have rediscovered the crucial significance of organizing. The recently concluded AFL-CIO convention was largely devoted to organizing manifestos and plans. ${ }^{1}$ Despite this awakening there is still disagreement and confusion about the causes or cures for labor's organizing setbacks. The official view held by a majority of labor leaders is that organizing failures are largely attributable to the changing workforce and to management's increasing use of sophisticated union-busting techniques without interference by the currently anti-labor National Labor Relations Board. The trend could be reversed by reforming labor law, or by changing the membership of the Board. Short of that, unions must appeal to the employees' self-interest by becoming $d i$ rect providers of economic benefits, and by promising that union benefits will continue regardless of the waning power of the labor movement. ${ }^{2}$ This view is a comfortable one for organized labor because it locates the causes of labor's difficulties outside the unions' areas of control and responsibility.

There is a minority view, however, which holds that labor's

$\dagger$ William K. Townsend Professor, Yale Law School.

During the winter and spring of 1971, I was a Visiting Professor at the University of Chicago Law School. One of the great and lasting pleasures of that visit was getting to know Bernie Meltzer. He is a friendly, gracious, and learned man with whom discussion is both enlightening and enjoyable. He has helped to make and keep the University of Chicago Law School the great institution it is, not only by his own outstanding work, but also by instructing and stimulating his colleagues.

' See AFL-CIO News, Nov. 19, 1985, at 1-4.

2 Since changes in law or policy are virtually impossible in the present anti-union political climate, the majority view tacitly admits that unions are not likely to win major concessions from employers in the near future. One response is the recently approved plan to offer associate membership along with insurance and other work-related benefits to employees not represented by unions in collective bargaining. See id. at 1, col. 2. 
organizing failures have occurred because unions have been complacent, have lost their sense of mission, have assigned incompetent people to organizing, and have failed to adopt innovative organizing tactics in response to changing conditions. ${ }^{3}$ They have not convinced the employees that unions represent the best pathway to needed change and increased dignity. Holders of this view believe that the political makeup of the Board is unimportant and that reform of the labor movement should be the unions' primary concern.

This article explains why those of us who hold the second view believe that the key to success for unions lies in the revitalization of the organizing process and in the careful selection and training of organizers. It also suggests that government regulation of the organizing process, particularly the extensive regulation of employer speech, has not been helpful to the labor movement.

The views explicated in this article have been developed through traditional academic study, a major field research project during which I interviewed hundreds of employees, formal and informal discussions with management and union officials, and research into the successful organizing drive conducted among clerical and technical workers at Yale University by Local 34 of the Hotel Employees and Restaurant Employees Union (HERE). I undertook to study the HERE effort at Yale in a scholarly way because, as an involved faculty member, I was struck by how different their approach was from typical union organizing efforts I had studied. Their organizers were more engaged with the employees, their tactics more imaginative, the rank and file more involved, and the spirit of union solidarity more evident. It did not surprise me to learn that HERE in New England was thriving-winning elections and adding members-while the union movement generally was suffering reverses. ${ }^{4}$

My interviews with the leadership of Local 34 disclosed that the approach they used was based on insights originally developed by Vincent Sirabella, currently Director of Organizing for HERE's international union. Sirabella has been a union activist for almost forty years. During all that time he has been both a thoroughly

${ }^{3}$ See, e.g., Baptiste, Modern Union Organizing Techniques and the Future of Collective Bargaining, 15 STETSON L. REv. (forthcoming Fall, 1985); V. Sirabella, Organizing in the 80's: Address before the Labor Conference on Organizing in the 80's, The New York School of Industrial and Labor Relations, Cornell University 3 (Jan. 12, 1985) (on file with The University of Chicago Law Review).

- During the period from 1979 to 1985, the union won 11 consecutive Board elections, the last of which involved Morry's Restaurant in New Haven. 
dedicated trade-unionist and a critic of the movement's leadership. Sirabella advocates unions based on rank and file involvement and control, and professional organizers recruited on the basis of zeal, ability, and social commitment. He has been willing to seek and train as organizers people who come from outside the ranks of organized labor. His first and most notable protege is John Wilhelm, the person who led the Yale drive and who was chief negotiator for the union thereafter. In the course of preparing this article I have had the chance to speak at length about union organizing with both Wilhelm and Sirabella ${ }^{s}$ and to study a document that Sirabella wrote for an AFL-CIO conference on organizing. ${ }^{6}$ The discussion that follows is based on all of the sources, scientific and impressionistic, described above.

\section{What Happens IN Union Organizing}

\section{A. The Union Start-Up Campaign}

Organizing drives arise out of discontent, often coupled with anxiety about changes in the enterprise. ${ }^{7}$ Employees who feel unfairly treated, inadequately compensated, and subject to arbitrary change will often be responsive to union overtures. Frequently they will themselves contact an organizer.

The central idea of unions. is and always has been the aggregation of employee power. The basic message is that the employees united will be far more powerful than they have been in dealing with the employer on an individual basis. Large unions like the Teamsters and the UAW promise not only the power of the employees in the unit but the power, wealth, and resources of huge organizations. This is one reason why employees thinking about organizing often contact the Teamsters despite their unsavory reputation.

- These interviews were conducted largely in the spring of 1985 , and were taped and transcribed. Transcripts are on file with the author.

- V. Sirabella, supra note 3. I have also discussed the dynamics of organizing campaigns at considerable length with Leland Cross, Esq., of the firm Ice Miller Donadio \& Ryan, which represents management on a regular basis. One of the things that have intrigued and influenced me is the fact that this successful management lawyer and this successful union organizer have strikingly similar views on campaign dynamics.

' See J. Getman, S. Goldberg \& J. Herman, Union Representation Elections: Law AND REALITY 142 (1976) [hereinafter cited as LAW \& REALITY]. The description of campaigns, and the quotations used to typify them, are drawn from the materials we collected as part of our study. Some of this material has also been published in J. GETMan \& J. BLAcKBurn, Labor Relations: Law, Practice and Policy 75-85 (1983) [hereinafter cited as Labor Relations]. 
An organizer who has decided that the prospect of success is sufficient to warrant an organizing effort will establish an organizing committee made up of employees, one function of which will be to persuade the workers to sign authorization cards designating the union as their collective bargaining agent. In order to convince employees to sign up, the union and its supporters will stress not only the prospect of improved wages and working conditions, but also the dignity that comes from having contractually-defined rights enforced through a meaningful grievance process and the fairness of using seniority as a technique for establishing priorities. Often union organizers will ask the employees about the changes they would like to see and then show them contracts from other bargaining units that have achieved these improvements. This is a powerful message to which very few discontented employees are totally immune. Where discontent is widespread, a high percentage of employees will often sign up fairly quickly. ${ }^{8}$

Accordingly, it is common for the first part of an organizing drive to be deceptively successful. In smaller units a majority will sometimes sign authorization cards before the employer knows that the campaign is underway or has a chance to respond. ${ }^{9}$ At this point it is almost always the case that a majority of employees wish to be represented, although the degree to which the employees support the union varies. Some are enthusiastic, life-long union supporters; others know little about unions. Some start from a questioning attitude, and some are hoping that the organizing drive will convince the employer to improve wages and working conditions in order to forestall unionization.

If the organizing effort is successful, the union organizer will write a "recognition letter" to the company's chief executive officer advising that the union has signed up a majority of employees, offering to prove this to an impartial observer, and requesting the company to enter immediately into a bargaining relationship with the union. The employer may respond to the request for recognition by entering into immediate collective bargaining with the union. Such action is legal if the union in fact represents an uncoerced majority at the time. But immediate bargaining is rare:

${ }^{8}$ Most unions do not collect dues from employees who sign up during this period. The prospect of paying dues to a union not currently capable of bargaining on their behalf might discourage some employees from joining. Moreover, union dues are certain to be a focus of the employer's anti-union campaign, and most organizers feel that the impact of this tactic can be lessened by waiving all dues until a collective agreement is signed. See R. WILliams, P. Janus \& K. Huhn, NLRB Regulation of Election Conduct 127-33 (1974).

- See LaW \& REALITY, supra note 7, at 135. 
most employers strongly desire to avoid dealing with a union, and they have a right to insist upon an election. ${ }^{10}$

If its request for recognition is rejected, the union's response is to file an election petition with the NLRB. The union's petition will specify which employees it claims to represent. The employer may then challenge the petition by arguing that the unit described is inappropriate under Board standards. ${ }^{11}$ The terms of the election and questions of eligibility are typically worked out by agreement of the parties. Usually it is the union that makes major concessions in order to forestall a Board hearing on these matters, since delay is thought to work in the employer's favor. ${ }^{12}$

\section{B. The Employer's Formal Election Campaign}

Employer campaigns are usually directed by a labor relations professional, either an attorney or a management consultant. The themes struck in the formal campaigns are remarkably similar across elections. To the union's basic message of change through solidarity, the employer's response is that things are not so bad now and that they could easily get worse with the selection of the union. The argument that things are not so bad is a staple of all management campaigns even when wages and working conditions are poor. Some variation of the following speech is almost always used. "In the past, the company has given you all the wage increases and fringe benefits it could afford and still stay competitive. We have given you these things voluntarily and without your having to pay one cent to any outsider or having to strike. We have done this because we want this to be as good a place for you to work as this company's financial ability and business will permit us

10 See Linden Lumber v. NLRB, 419 U.S. 301, 309-10 (1974).

11 The employer's challenge is typically based on one of several tactical considerations. The employer might seek to reduce the number of people in the unit to weaken the union's bargaining power if it is successful. The employer might try to alter the unit (usually by enlarging it) so as to minimize the union's chances of winning the representation election. The employer might also raise issues about the bargaining unit in order to delay the election to gain more time to convince the employees to vote against the union. Finally, the parties might also disagree about which employees are eligible to vote in a given unit.

12 The Yale drive was an exception in this regard. During the Yale drive, the union anticipated that the administration's lawyers would try to delay the election by litigating unit questions at length, which they in fact tried to do. The union responded by bringing busloads of employees to the hearings and then issuing flyers in which these employees protested what they perceived as the administration's shameful stalling. The tactic worked so well that after about two weeks the administration agreed to a unit quite favorable to the union. 
to do."13 An implicit part of this argument is that the financial interests of the employees are inevitably tied to the employer's profitability. The union does not realize this and thus endangers both the employer and the employees. As one employer speech put it, "We are not ashamed of being interested in profits. After all, if it wasn't for profits, there would be no reason for us to stay in business or provide jobs for you."14 If wages are low and working conditions poor, the company will stress job security or the fact that management was willing to do small favors for employees, such as giving them time off in emergencies, loaning them money, or permitting them to exchange shifts. The employer will claim that such behavior will become impossible once a union is on the scene and a collective agreement in force. ${ }^{15}$

Employers argue that wages and working conditions will not be improved by collective bargaining. The theme that "the union can guarantee nothing" is always raised: employers point out that the law does not require them to agree to the union's proposals. ${ }^{16}$ It is common for employers to announce that they intend to bargain tough ${ }^{17}$ - that if the union insists upon trying to make major changes, the result will be a strike which will have awful consequences for the employees. Almost all campaigns include an argument like the following: "Strikes are a brutal and unpleasant experience. You get no wages, no unemployment compensation, and new employees may be hired to permanently replace you. Strikes generate ill will. Violence is not uncommon . . . . Management loses during a strike too. In a strike everyone loses, except

13 LABOR RELATIONS, supra note 7, at 77-78.

14 Id. at 80.

15 The following excerpt from a speech by a professional management consultant is typical of this argument: "Now this shop has a lot of women. Many of you girls are the sole support of your family; you've got children, you do the best you can to get a babysitter, but sometimes things go wrong. And I resent deeply to be bound by a union contract that says when somebody exceeds a limit of, say five days a year, I've got to let her go regardless of the reason she was out. That's no heart! When we lose sight of the fact that a company exists to serve people we're in trouble!" Id. at 78.

18 Some employers will distribute "guarantee letters" that contain a series of promises purporting to come from the union about the gains they will achieve. On the bottom is a space for the organizer's signature. It is assumed that the organizer's refusal to sign demonstrates the union's powerlessness.

17 A speech like this one might be used: "The only way a union can attempt to force your company to meet unrealistic union demands would be to pull you out on strike. Now without intending to seem harsh or abrupt, I hope you will realize and understand-while there is yet time-that we have no intention of yielding to any such pressure as that ever." LABOR RELATIONS, supra note 7, at 78. 
the union organizer. He will draw his pay fifty-two weeks a year."18

All employer campaigns suggest that the advent of the union might harm employees economically. ${ }^{19}$ Employers almost always seek to place the responsibility for such harm on the union, even when the employer's response to the union is part of the described course of events. Not all employer statements make it clear that the harm will result from factors beyond the employer's control. ${ }^{20}$ Some leave the source of the harm somewhat ambiguous, and others either suggest or announce that the employer will take reprisals against the employees if they vote for the union. Some employers go even further and actually take reprisals against union supporters during the course of the campaign in order to add to the employees' fear of the consequences of unionization.

Even when the employer conducts an aggressive campaign that includes reprisals and threats to "bargain tough," it is common for the campaign literature to take a friendly tone, using first names on salutations and closings as if to demonstrate the employer's other, more humane, side. Frequently the literature will purport to correct factual errors in the union's campaign or to convey information about the election process in a disinterested fashion. Such propaganda may be labeled a "fact sheet" or "information bulletin" to contrast it with "irresponsible" union claims. ${ }^{21}$

A significant part of almost all management campaigns is the

${ }^{18}$ Id. at 78-79.

10 Generally a variation of the following argument stated by a manufacturer of industrial seats is used: "Our company is the sole supplier that many of these customers have. What do you think these customers would do if we became unionized? They would buy half as many seats from us as they are now and obviously this would reduce our business and it would reduce our employment." Id. at 80.

${ }^{20}$ See NLRB v. Gissel Packing Co., 395 U.S. 575, 618 (1969) (requiring that employer statements, to be protected under $\S 8$ (c) of the National Labor Relations Act, 29 U.S.C. $\S 158$ (c) (1982), make clear that the economic consequences they describe are beyond the employer's control).

21 Sometimes the literature will take the form of responses to fictitious employee questions:

Dear Ed: I would like to share with you some of the typical questions we have heard from our employees in the past few weeks.

"Who would be the union leaders and officers, if the union wins? . . " You all know the answer to this question by just looking around the plant. Only a very few will profit in this regard from this union.

LABOR RELATIONS, supra note 7, at 81.

The Yale administration issued "Election Fact Books," complete with footnotes, which purported "to answer questions that have been asked about the important issues confronting anyone who will vote in this election." The questions included "Will I have to go on strike?" and "Who controls the Hotel Employees and Restaurant Employees International Union, and how does it control its locals?" 
argument that the union organizers are outsiders, interested in the employees solely as a source of dues and initiation fees. ${ }^{22}$ Employers argue that because the union is run by outsiders who are not really interested in the employees, it will inevitably create a less friendly and more adversarial relationship between management and labor. Because the union leaders have no stake in the company, they will be willing to jeopardize its future and the jobs of the employees in order to demonstrate their power. The employer may agree that unions make sense in other industries or that they did a lot of good once, but will argue that they are no longer needed and have become too big, rich, and removed from the true interests of working people. ${ }^{23}$ Even if the employer's campaign denies general anti-union bias, it will often include an attack on the union conducting the organizing drive as particularly corrupt, strike-prone, inappropriate for the employees, or insensitive to their needs.

Another important part of almost all employers' campaigns is the message that they are sensitive to the concerns which led the employees to consider unionizing and that, given a chance, they will improve things on their own. ${ }^{24}$ They will suggest that were it not for legal restrictions they would be able to be more specific about the improvements they intend to introduce. ${ }^{25}$

\section{The Informal Management Campaign}

In addition to developing the formal themes used in speeches and campaign literature, the labor relations professional will try to establish a managerial style during the campaign which will help to

${ }^{22}$ A typical employer letter making this claim states: "What the union organizers want is money. Your money! These union organizers are out here for the thousands and thousands of dollars that they hope to get out of you in the form of initiation fees, union dues, and union assessments. You must decide whether to let these outsiders get their hands in your pockets. But make no mistake, it is your money that this union is really after." LABOR RELATIONS, supra note 7, at 79.

${ }^{23}$ An employer might argue as follows: "Now I'm not going to say that unions haven't done a fine job ..... In years gone by, I'm sure John L. Lewis did great things for the coal miners, but let's take a good look at unions today. They're big, they're rich, they've got investments in Florida, big night clubs down there .... They are paying themselves $\$ 150,000$ bucks a year . . . Do you want to give them more money to squander on these things?" Id.

24 A typical company statement concludes: "Why pay dues and why run the risk of a union forced strike . . . to get what you can get free to you." Id. at 80 .

${ }^{2 s}$ The following approach is common: "People say we need a pension program . . . . I want you and the National Labor Relations Board to understand that I am not promising you anything, but one of the things we have been kicking around and talking about is what we call income protection insurance." Id. 
convince employees that it is futile or risky to vote yes and that improvements will likely follow once the union is defeated. The mood is created through a variety of basic stylistic decisions. These include how active a campaign to conduct, how much to involve lower-level management in the process, how overtly to try to arouse fear of the employer's response to unionization, whether to use question-and-answer sessions, and whether to make a serious effort to keep the campaign within the law.

Almost every professional has certain tactics that he or she regularly uses. Some typically instruct management to give employees two paychecks sometime close to the election, one consisting of the amount of union dues which would be deducted from the employees' pay under a union contract and one for the balance. Some favor handing out "guarantee letters" which the employees are asked to present to the union organizer for signature. Some professionals like to conduct a survey in which employees are asked questions about their job attitudes in such a way as to suggest that changes will be made without falling into the legal traps of soliciting grievances or promising benefits. Many professionals routinely employ delay, litigating questions about the election at great length in hopes that time will cool the employees' ardor for the union and demonstrate the union's impotence. Employers are often urged to get tough, to discharge employees thought to be union sympathizers as soon as they step out of line in any way. Some professionals urge their clients to act friendlier and more accommodating, while most suggest a business as usual approach.

During their practice most consultants develop a style that they regularly employ. This, together with the similarity of formal campaigns, means that a well-informed union faced with a campaign run by a known management consultant can anticipate with considerable assurance what kind of tactics it will face.

\section{The Union's Response}

Unions have standard campaign tactics and arguments to counter each of the employer tactics described above. Union literature will stress that in the vast majority of cases contracts are negotiated without a strike, and it will add that decisions concerning bargaining positions are made by the employees themselves. Often the union will affirm its desire to be reasonable and permit the employer a fair profit.

Experienced organizers will turn around the argument that they are unable to guarantee improvements. One organizer presented with an employer's guarantee letter explained his refusal 
to sign as follows: "What you get from the Company isn't up to me, it depends on how strong you are and what you want. It's your local union, and if you support it, you'll be successful."26 The union may issue a guarantee letter of its own promising that no strike will be called except by a two-thirds vote of the employees and pledging not to collect dues until a collective bargaining agreement is signed with benefits far greater than the dues. Unions will respond to claims of personal favors to employees by arguing that such favors would not have been necessary in a unionized shop. ${ }^{27}$ Most unions will stress that they are an accepted part of the American industrial system. They have in their files pro-union statements from noted public figures of all political persuasions and from varied ethnic backgrounds. Which quotes are used in a particular election depends upon the makeup of the work force. Various papal statements are used where Catholic workers are involved. If a sizeable number of black voters are in the unit, a union may quote Martin Luther King's comment that "the labor hater is always a two-headed creature spewing anti-negro talk from one mouth and anti-union propaganda from the other."28

If promises or improvements are made by the employer the union will claim credit for them. A typical union letter argued, "It took Local 561 to make the company discuss your needs, but have you been promised anything definite? Is it in writing? Is it signed? Whose word do you have that conditions will improve? The word of the company? Up to now it hasn't been worth much to you."29

The union is almost certain to criticize the employer's campaign. It will claim that the employer is trying to win the election by unfairly frightening the employees or by trying to buy them off. Increasingly unions make the company lawyer or management consultant an issue by attacking both the unfair style and the high fees. "It's a shame that the tremendous fee that is being paid Mr. Flynn is not used as pay raises for you, instead of its being used for scare letters." 30

${ }^{26}$ Id. at 83 .

27 A variant of the following argument might be used: "Mathews claims to be proud that employees have come to him with family, personal, and financial problems. Most or all of these problems have been financial. The employees had a problem living on the wages paid by the company .... This is not the type of problem Mathews should be proud to have his employees discuss with him. The answer to your problems is not to go to the plant manager. The answer is your union!" $I d$.

${ }^{28} I d$. at 84.

${ }^{29}$ Id.

${ }^{30}$ Id. 
Unions respond to the argument that they are outsiders by stressing local control. "You are the union" is a line used in virtually every union campaign. Large unions will stress their power. "Local 743 has the full support of the Teamsters Union. The largest and strongest union in the world." 31

\section{E. The Response of Employees to the Campaigns}

1. The basic dynamic. Employee reaction varies in accordance with the personalities, fears, hopes, union attitudes, and levels of job satisfaction of the people in the unit. ${ }^{32}$ No simple model can do justice to this complex reality, but certain generalities can be drawn and others inferred from the available data.

Employees who are both favorable to the organizing union and dissatisfied with their jobs perceive and respond to the campaign differently from employees who are satisfied with their jobs and either unfavorable or indifferent to unions. Neither of these two groups is likely to be affected by the actual campaign, since their commitment is strong and their perception selective. The former perceives the employer's campaign to be far tougher and more threatening than does the latter. Pro-union employees assume that any discharge during the course of the campaign was for union activity, and they find threats in ambiguous statements. These perceptions do not alter their willingness to vote for the union. They are instead confirmed in their conclusion that the employer is unfair, not to be trusted with total power over their jobs. Employees who are satisfied with their jobs perceive the employer's campaign in much friendlier terms. When asked about the content of an employer talk they are far more likely to report that "he was very fair. Told us to make up our own minds" or that he "told us the pros and cons of voting for the union." 33

The employees whose votes may be affected by the campaign are those who like their jobs in general but feel that they are unfairly treated in some important way, who are favorable towards unions in general but who doubt the particular union's commitment or ability to improve things for them. Any employer campaign, even one that is limited to a simple sign saying "Vote No," will stir their apprehension by announcing that the employer is against unionization and that the advent of the union will not

31 Id. at 85 .

${ }^{32}$ See generally LAW \& REALITY, supra note 7, at 53-72, 141-46 (discussing the importance of employee predispositions).

${ }^{3 s}$ See id. at 120-29. 
bring about change without struggle. A campaign that also demonstrates concern for the employees will convince some of them to wait and see what benefits they will get without the union. Faced with upsetting changes in company management or rumors of plant relocation, employees will often sign authorization cards but may be persuaded during the campaign to give the employer another chance and vote against representation. ${ }^{34}$

Employees will also try to determine whether the union will be fair, reasonable, and democratic. They feel that they have something to lose if the union is too rigid or adversarial. Some employees are likely to decide to vote no even if they would vote for representation were a more effective or responsive union to come along. It is often the case that the local asking for the employees' votes is new; the organizer is likely to be a stranger to all or most of the employees. Since the organizer initially stands for the union, the employees will be likely to study her behavior for clues as to how the union will perform. In a typical campaign, at least some employees mildly favorable to unionization as an abstract concept will conclude on the basis of such observations that the particular union is unworthy of support.

The willingness of employees to give the employer another chance and their frequent negative conclusions about a particular union mean that unions which have secured card majorities often lose election campaigns. The gap between card majority and final outcome has helped to generate two related misconceptions: first, that employers generally win representation campaigns by frightening employees into voting against representation; and second, that management consultants are particularly skillful in devising means of frightening employees to achieve this purpose. In analyzing our data prior to writing Union Representation Elections: Law and Reality, ${ }^{35}$ my co-authors and I devoted the major part of our analysis to the question of whether successful employer campaigns could be attributed to the kinds of employer acts or statements that the Board deemed likely to coerce employees into voting

${ }^{34}$ Id. at 146 ("If the employer's campaign does no more than remind employees that things are pretty good without the union, it may gain the support of some employees not wholly satisfied with working conditions, but also not wholly in favor of unions.").

${ }^{3 s}$ Supra note 7. This work was the result of a major study of Board elections that I undertook with Professors Goldberg and Herman during the early seventies. Our purpose was to test the assumptions about employee voting behavior that underlie regulation of campaign conduct by the Board and the courts. Knowing how controversial the legal question of campaign regulation is, we designed our study with great care and reported only those findings which we felt certain were scientifically supportable. 
against representation. We found that successful campaigns were not marked by an unusually large number of employer unfair labor practices or employee reports of threatening statements, nor did employees explain their votes or those of their co-workers in terms that suggested fear of employer reprisal. ${ }^{36}$ We concluded from these data that employee voting choice is not as easy to manipulate as the cases suggest-that no significant advantage accrues to an employer who commits unfair labor practices or violates one of the "laboratory conditions" standards during the course of a campaign, as contrasted to an employer who conducts a vigorous legal campaign. ${ }^{37}$

This is not to say that fear of economic consequences plays no role in thwarting unionization. Concerns about the economic consequences of unionization and the possibility of employer retaliation are present before organizing ever begins. Indeed these concerns often prevent employees from seriously considering unionization until their dissatisfaction or concern about existing conditions becomes great enough to overcome their fear. It is precisely because these fears are present before and throughout the campaign that they are so difficult to manipulate successfully.

As to the second misconception, the effectiveness of management consultants, all of the management campaigns that we studied in working on our book on representation elections were directed by labor relations professionals. We interviewed all but one of these professionals at length shortly after the election. They were in general earnest but not terribly imaginative people. We did not find them to be the skillful manipulators of employee sentiment they are sometimes made out to be. In particular, those who regularly used illegal tactics seemed to have less awareness of campaign dynamics than those who did not. The campaigns that they conducted were based on simplistic models of employee behavior and did not depart from predictable themes and tactics. I was therefore not surprised when John Wilhelm told me that because they are so predictable, he is delighted to learn that a management consultant is running the employer's campaign when he is involved in a representation election. ${ }^{38}$ I consider the reputation of virulent anti-union consultants for great skill in manipulating employee

se See id. at 100-02, 113-16.

${ }^{37}$ Id. at 128-29. We also concluded that unions are at a disadvantage compared to employers in getting their message to the employees. Id. at 95-96.

3s Interview with John Wilhelm at Yale University (Spring 1985) (transcript on file with author). 
voting behavior to be one of the great myths of labor relations. This myth persists and expands because its propagation is in the interests both of the consultants, who derive business from being perceived as tough and effective, and of the union organizers, who can then explain their failures in terms of the skill, resources, and ruthlessness of their opponents.

This is not to say that union organizers are being dishonest, but rather that it is a welcome conclusion to explain an otherwise surprising loss. Furthermore, the organizers learn much of what they know about the effectiveness of the campaign from the employees who support the union. If the employees from whom the organizer gets information are inaccurate, the organizer is likely to be misled. In one of the campaigns we studied in which the employees voted against representation after the union had obtained a card majority, the organizer told me that he thought the management campaign was effective for two reasons: the employer threatened the employees with reprisal, and the employer pointed out that employees were subject to arbitrary treatment and unreasonable fines under the international union's constitution. The organizer thought that the latter issue had been particularly effective. But during our interviews, only four employees mentioned this issue-and all of them had voted for the union. The organizer obviously thought this issue was effective because it stirred up some of his most loyal supporters. A similar dynamic took place with regard to the employer's allegedly threatening behavior. This is quite common. Organizers regularly reported that the issues which moved the electorate were the ones that impressed their strongest supporters. These were not, however, the issues mentioned by the employees who had signed authorization cards but later voted against representation. These employees rarely tell the organizer why they shifted their allegiance. Even if they do, they are likely to tell the organizer that they acted out of fear, rather than in response to the organizer's inadequate performance.

2. The successful employer campaign. Although our study showed that employer coercion and professional expertise do not play as significant a role in election outcomes as commonly thought, we did not develop a scientifically supportable conclusion concerning the positive elements of a successful employer campaign. On the basis of my observations, however, I have found that the successful campaign achieves two objectives: it sustains and increases the employees' concern about how the union would perform if chosen, and it convinces employees that the employer's past record shows that it deserves their support, or at least a sec- 
ond chance. ${ }^{39}$

During the course of our study I did an analysis of reasons given by employees for their votes. I divided the reasons given by employees into those denoting positive feelings towards the employer (such as loyalty, satisfaction, and the hope for improvement) and those denoting negative feelings (fear of retaliation or other harmful consequences should the union be chosen). I found that the ratio of positive to negative reasons was far higher in successful employer campaigns-campaigns in which a high percentage of card-signers or employees who originally intended to vote for representation ending up voting no. The scale was my own and I developed no sharply defined standard for allocating reasons to categories. Accordingly, my colleagues quite properly concluded that these data had no place in a scientific report of our conclusions. Yet these data conformed so well to the impression I got from talking to the employees during and after such campaigns that I have since felt that this non-rigorous method captured a great truth. Appeals to loyalty in an employer campaign are much more potent than threats, which fit better into the image of unfairness that unions generally seek to exploit. Employer threats often underline for employees their need for protection.

3. The successful union campaign. The employer enters most campaigns with three advantages. First, it has instant and prolonged access to the employees. Second, it can offer to employees the possibility of improvement without cost and without the creation of a new bureaucracy. Finally, it can play on the fact that most people find the thought of substantial change in their lives frightening. It is the task of the union organizer to overcome these disadvantages or even to turn them to the union's benefit. She must find a way to get her message heard by the uncommitted employees. She must convince them that the union is composed not of outsiders but of concerned fellow employees, that the changes which the union proposes are worth fighting for, that the union will be able to protect employees against reprisal, and that the union's officials can be trusted.

a. The Relationship Between the Organizer and the Employees. The organizer must get to know the employees and address their particular concerns. She cannot rely on routine campaign tactics and messages; prepackaged materials, no matter how well prepared, are inadequate. This is a tremendously demanding task. To

39 See Law AND Reality, supra note 7, at 108. 
do it successfully requires a rare combination of sensitivity, toughness, and enthusiasm. The organizer must also work to develop a strong internal organization. This is a crucial part of the union campaign. It is the inside organizing committee that conveys the union's message directly to those employees who do not attend union meetings. The committee, made up of employees, constitutes the best response to the argument that the union is run by outsiders unaware of and indifferent to the needs of the employees. Moreover, as previously noted, without an effective employee team the professional organizer will not understand campaign dynamics and may fail to recognize the crucial local issues.

The key to developing broad-based activism is the ability of the organizer to convey her own commitment and concern. One-onone meetings with employees, getting to know who they are and what they care about, are crucial to the organizer's success. Organizers who reject or try to minimize home visits on the grounds that the employees will resent interference with their free time are mistaken. Employees have strong views about their jobs that they are eager to tell to someone they think really cares. I learned that this was particularly true of employees who at first seem indifferent to the campaign and unwilling to talk to anyone about it. Such employees are frequently expressing more than anything else the sentiment that "no one really cares about what I have to say because I am uninformed and confused."

Because the employees use the campaign to evaluate the union, mistakes by the organizer are more likely to be costly than are mistakes by the employer representative. During the course of my study, I felt on several occasions that unions lost elections which they could have won but for campaign errors. The most common mistake was failure to convey personal interest in the employees. This mistake took several forms: over-reliance on formal campaign literature, too many mass meetings, working almost exclusively with one or two people on the employee committee, and most significantly, not getting to know the rank-and-file members. A second common mistake is the use of personal attacks on individual members of management. These, unless very carefully and skillfully done, are generally thought to be unfair by undecided workers, and they give support to the management claim that unions are divisive.

b. Who Speaks for the Union? The best organizing efforts constantly put forward the employee voice as the voice of the union. Curiously, my experience suggests that the importance of projecting the rank-and-file voice seems to be best understood by 
organizers who did not themselves come from the rank and file-perhaps because organizers who came out of the ranks have difficulty realizing that the employees no longer perceive them as "one of us." Most of the Yale organizers began as outsiders to the labor movement: they were college-educated people who first learned their craft doing community organizing. They were careful not to represent themselves as the rank and file, nor to speak as though they were the most important part of the organizing process. They kept stating to me that the committee organizes the employees and that their own job was to support the committee. The only staff person who regularly spoke for the union was John Wilhelm, who made it a point never to appear by himself at a public meeting and to let the rank-and-file people take the lead. The great majority of those who spoke at union meetings and public rallies were clerical and technical workers rather than organizers. Most had little previous experience addressing meetings. By the end of the strike the union had developed a group of speakers, mostly women who had been at the university for many years, who were notable for their eloquence and their sincerity.

A sense of the potency of this approach is conveyed by a Yale clerical worker who later joined the staff of the union:

I was brought on by one of the paid organizers .... She pulled me forward. In fact in this union one thing that happens . . . is that you can be catapulted to great heights within a small amount of time. I came on in August and in November I'm speaking at a big rally. It's crazy! . . . There was a reason that I became involved then and didn't earlier, and that was because I realized that this was a very different organizing drive, and I have seen some of the others and they just weren't the same. They weren't built from the bottom up like this union was .... [T] through some sort of grapevine . . . built a committee of 500 people. That was such a tremendous base from which to begin that it was a much more personal sort of thing than leafletting on the street corners, which is what we'd done in the ' 77 drive. ${ }^{40}$

40 Interview with Lce Berman at Yale University (Spring 1985) (transcript on file with author). For a description of the very effective women speakers involved in the strike, see Ladd-Taylor, Woman Workers and the Yale Strike, 11 Feminist Studies 465 (1985). In addition to the major speakers there were people like the law school's Isabel Poludnewycz, whose leadership, warmth, and organizational skills helped to make the law school staff the strongest union group on campus. 
The process by which rank-and-file leaders and other potential union activists are identified and encouraged to participate in the union is complex. The organizer must be aware of the employees' fears and concerns but not overcome by them. The psychological astuteness necessary for this task is suggested by an interview that I conducted with a rank-and-file activist who had played a major role in the Yale organizing drive and strike.

Getman: "Did you feel pushed by the union?"

Andrea: "I wanted to be pushed. I really enjoyed taking on more and more ... but there were times when they pushed me to do things that I felt were difficult or didn't want to do, but afterwards I felt good about it."

Getman: "Such as what?"

Andrea: "Like this building . . . where there's this group of anti-union people. They were extremely hostile and it was much easier for me to ignore them and speak to people who were receptive . . . but [an organizer] was pushing me and we went in there and had a couple of major arguments and afterwards I felt good that I did it and the next time it wasn't quite so difficult." 41

This story reflects how sensitive a good organizer must be. If the organizer had been wrong in thinking that Andrea would do well in such a situation, the approach might have backfired. Organizers who are less perceptive tend to be more passive than the organizer was in this situation-which is why few are as good.

One result of this emphasis on the employee voice was that many of my Yale colleagues were astonished by the number of articulate and committed rank-and-file people who emerged to speak for the union during the organizing drive and subsequent strike. Some concluded that this phenomenon was a special tribute to the high intellectual caliber of Yale employees. John Wilhelm does not agree. He believes that such people are regularly present in any substantial work force, and that the job of the union organizer is to seek them out and encourage them to speak out. All my own experience supports his conclusion.

c. Immunization. A skillful union organizer may blunt much of the employer's campaign by predicting it. This permits the union to take credit for the implied promises and reduces the fear of harmful consequences by showing that such claims are an ex-

41 Interview with Andrea Ross at Yale University (Spring 1985) (transcript on file with author). 
pected part of the employer's campaign. A Teamsters organizer in Indiana whose success rate was excellent used to read publicly at one of his early meetings from a pamphlet instructing employers about how to defeat a union organizing campaign. He would post a list of employer campaign statements and tactics on the union's bulletin board and check them off when they occurred.

In its organizing drive at Yale, Local 34 introduced someone at a meeting whom they described as a member of the Yale personnel department, who was being given a chance to speak in the interest of fairness. This person, in reality a teacher and a strong union supporter, made all the traditional anti-union arguments with such force that many employees were incensed and many others swayed. Afterwards, union officials conducted critiques of these arguments. Although the benefits of this tactic, referred to as "immunization" by Local 34, seem to me obvious, it is not used by most organizers-some because they do not want to give exposure to antiunion arguments, some because they are not sure of how to respond to those arguments.

d. Fervor. The union movement which Vinnie Sirabella joined in the 1930s used passionate oratory, protest songs, and personal testifying to organize. His first exposure to the cause of unionization came when he listened to Anna B., "The Red Flame," orating in the Balbo Hill district of Providence, excoriating the bosses and the political system which permitted exploitation. ${ }^{42}$ Today such passion is generally missing from union organizing, which is much more based on carefully worded rational argument and economic inducements. ${ }^{43}$ Yet, as modern evangelicals exemplify, passion is still a vital part of commitment. The Yale representation campaign had a religious flavor. People told of their earlier failures and temptations and of their ultimate redemption and rebirth. When Lucille Dickess described how she had fought unionism in the past and how she had become converted by realizing that the University officials did not truly respect her, people wept, cheered and stood up to applaud her. The union conducted candlelight vigils and silent witnesses, and engaged in acts of civil disobedience. One of the organizers told me that he wept at every rally the union

${ }^{12}$ Interview with Vincent Sirabella, New Haven, Conn. (Spring 1985) (transcript on file with author).

43 Indeed, the AFL-CIO, adopting an approach suggested by Professor Medoff, hopes to turn its organizing failures around by offering "associate membership" to employees who join up to obtain special economic benefits (such as insurance) through the union. See AFLCIO News, Nov. 9, 1985, at 1, col. 2; J. Medoff, The Public Image of Labor and Labor's Response 37-38 (Nov. 1984) (on file with The University of Chicago Law Review). 
conducted. These are not only the tactics of organizing but of commitment, and it is this more than anything which marked the Yale drive and permitted the union to conduct an effective strike.

When the union asked people to sign authorization cards, it also passed out a paper instructing people not to sign unless they really wanted the union and intended to join up. When employees expressed a willingness to sign up but not to become active, they were frequently told that the union did not have such a category of membership. An older employee who had previously been in two other unions told me that Local 34 was the most demanding organization he had ever been involved with. A very large percentage of the members were on one union committee or another. The reason why the employees did not feel exploited was because their own commitment was matched by that of the organizers, who were as notable for their passion as for their youth and intelligence. As one of the organizers told me, "I do think there was an incredible investment on the part of us in the workers' lives . . . . I'm not saying that that was unique or anything, but I think that there was real strength in that. We were not just professionals, we were right in there, and so I was moved constantly by what was going on." ${ }^{44}$

Vincent Sirabella does not think that effective organizing can be conducted in the private sector unless the organizer is passionate, committed, and capable of stirring others. This does not mean ranting or crying, or even being eloquent. It means caring deeply and communicating that to the employees. The task is a complex and demanding one. Yet the problems that underlie the labor movement's failures in organizing reflect not merely the difficulty of the job, but also the low priority which the labor movement assigned to this most crucial task. There is surprisingly widespread agreement within the labor movement that for a long time the unions' ablest people have sought and received jobs doing collective bargaining and grievance handling instead of organizing. Donald Ephlin, now Vice President of the United Auto Workers in charge of their General Motors division, told me that during the sixties and seventies almost all unions undervalued the importance of organizing. ${ }^{45}$ Many unions overestimated their own strength-they were satisfied with their membership and did not recognize the need to expand. Vinnie Sirabella stated recently that the labor

44 Interview with Paul Clifford at Yale University (Spring 1985) (transcript on file with author).

t5 Conversation with Donald Ephlin in New Haven, Conn. (Sept., 1979). 
movement has ignored the need to organize for over two decades. ${ }^{46}$

Having worked with both union leaders and rank-and-file people for many years, I have been struck by the failure of most unions to draw on the tremendous amount of talent, intelligence, and dedication to the labor movement among the rank and file. Staff appointments too often are determined by internal political considerations rather than by ability. Indeed, employees likely to threaten established ways of doing things are often automatically excluded from leadership positions. It is not atypical that Vinnie Sirabella, long an outcast in his own union, preached the importance of adopting new organizing techniques for years before the leadership of his union paid any attention to him. What is surprising is that he had the patience and strength of character to persevere, and that he responded with enthusiasm rather than anger when the international union finally decided to adopt the methods which he had urged on them for so long in vain.

\section{Regulation in the Organizing Context}

If my description of campaign dynamics is accurate, it follows that the tremendous concern which the Board has lavished upon the nuances of employer conduct and speech has been beside the point and misleading.

Given the fact that the first amendment protects an employer's right to speak against unionization, ${ }^{47}$ the practical difference between legal and illegal employer campaigns will continue to be insignificant. Employers by the very fact of a campaign may arouse anxieties and concern, but they will not affect more votes than they could have swayed by making traditional legal antiunion arguments. Indeed it seems likely that the most effective employer campaign is a legal one which plays upon employee loyalty and fear of the union rather than on fear of the employer. The two major empirical studies of the impact of employer unfair labor practices have both concluded that they make no difference. ${ }^{48}$ In Law and Reality, we urged on the basis of such data that the Board stop regulating employer speech and eliminate the "laboratory conditions" approach and the various doctrines which have

18 V. Sirabella, supra note 3 , at 3 .

17 See NLRB v. Gissel Packing Co., 395 U.S. 575, 617 (1969) (§ 8(c) "merely implements the First Amendment").

4s See LAW \& REALITY, supra note 7, at 128-30; Cooper, Authorization Cards and Union Representation Election Outcomes, 79 Nw. U.L. Rev. 87, 114-18 (1984). 
developed under it. ${ }^{49}$ Our recommendations have been opposed on a variety of grounds. ${ }^{50}$ Many have claimed that they are potentially dangerous to unions and if followed would present employers with an opportunity to escalate their use of fear and coercion. Even those who doubt the efficacy of Board regulation assume that it is worthwhile on the chance that it provides unions with a degree of protection against employer intimidation. ${ }^{51}$ These arguments assume that Board regulation works in favor of the unions if it works at all; since unions are currently doing badly in contested elections, a suggestion to reduce Board protection is particularly ill-timed.

At one time I accepted the logic of this position, but I have become convinced that the price, both legal and practical, which the unions have paid for the regulation of employer speech has far exceeded the possible benefits. My conclusion rests on two premises: first, that when the Board intervenes in an election on the union's behalf, the union rarely benefits; and second, that the current trend in the law to ignore legitimate and important union interests is due in part to a desire to preserve "balance" in the face of what is perceived to be unusual administrative and judicial protection of unions.

19 LAW AND REALITY, supra note 7, at 159. The Board's response to our recommendations was very negative. In General Knit of California, Inc., 239 N.L.R.B. 619 (1978), the Board majority stated that this " 1 study of only 31 elections in 1 area of the country-although it may provide room for thought-is simply not sufficient to disprove the assumptions upon which the Board has regulated election conduct." Id. at 622 . For a discussion of the inadequacy of the Board's treatment of the study, see Shapiro, Book Review, 86 YALE L.J. 1532, 1543 (1977). See generally Goldberg, Getman \& Brett, Union Representation Elections: Law and Reality: The Authors Respond to the Critics, 79 Mrch. L. REv. 564, 573-80 (1981) (discussing the Board's response) [hereinafter cited as The Authors Respond].

so See, e.g., Eames, An Analysis of the Union Voting Study from a Trade-Unionist's Point of View, 28 Stan. L. Rev. 1181 (1976); Kochan, Legal Nonsense, Empirical Examination and Policy Evaluation, 29 Stan. L. Rev. 1115 (1976); Weiler, Promises to Keep: Securing Workers' Right to Self-Organization Under the NLRA, 96 HaRv. L. REv. 1769, 1783-84 (1983); Peck, Book Review, 53 U. WASH. L. REv. 197 (1977); Shapiro, supra note 49. See generally The Authors Respond, supra note 49, at 580-93 (discussing critics' response).

s1 In an influential article, Paul Weiler wrote:

It may be legitimate for Getman and his coauthors to conclude that their own data do not demonstrate with certainty that employer coercion affects employee voting, but it is entirely unjustified to infer from that fact alone that the contrary is true. The failure to find a statistically significant connection between employer intimidation and employee votes in this limited sample neither proves that there is no such relationship nor provides a basis on which to argue that we may safely abandon efforts to protect employee choice. . . . Given the inherent plausibility of the notion that employees will respond to threats to the jobs that are crucial to their lives, and given that the data in the Getman study indicate that it is more likely than not that such threats do affect employee votes, it is only prudent to take steps that will ensure freedom of choice in the workplace.

Weiler, supra note 50, at $1783-84$. 


\section{A. The Effects of Board Intervention}

When the Board finds that an employer has violated one of its rules in the course of a campaign, its normal remedy is to set aside the election and order it reheld after an appropriate period. Board reports show that unions lose re-run elections in the great majority of cases. ${ }^{52}$ Unions are aware of this, and sometimes do not even wage a campaign. Union victories in subsequent elections are due to the employees' perception that the employer has no intention of making good on the implied promises made during the campaign. It takes time for the realization to spread and sink in that unless there is a union, things will go on as they always have. By the time it does sink in, almost invariably a year will have passed and the union will be able to petition for a new election without the Board's intervention. ${ }^{\text {s3 }}$

The effectiveness of the Board's remedies against employer unfair labor practices during an organizing campaign thus turns largely on the bargaining order, by which an employer who has committed serious unfair labor practices is required to bargain with a union that has a card majority even though the union did not capture a majority in the election. ${ }^{54}$ At first blush the bargaining order seems to be extremely powerful, effective enough to remedy the particular violations to which it is applied and to deter other employers from committing similar unfair labor practices in the future. What evidence we have, however, suggests that bargaining orders are far less potent than they first appear. Unions that obtain bargaining orders often do not obtain contracts. ${ }^{55}$ The reason is apparent. A bargaining order is indirectly an admission that the union does not represent a majority of employees. A union that does not speak for an active majority is in a terrible position when it comes to obtaining concessions from an employer. ${ }^{56}$ Thus the union must either accept a weak contract or face the prospect of an

${ }_{52}$ See Pollitt, NLRB Re-Run Elections: A Study, 41 N.C.L. REv. 209 (1963). According to Pollitt's study, unions that obtained re-run elections on the basis of employer unfair labor practices won only $30 \%$ of those elections. Id. at 212 .

ss See National Labor Relations Act § 9(c)(3), 29 U.S.C. § 159(c)(3) (1982) (requiring one year between elections).

s4 See NLRB v. Gissel Packing Co., 395 U.S. 575, 597-603 (1969) (holding that a card majority can serve as the basis for an obligation to bargain if an employer's coercive conduct rendered cards a better indicator of employee choice than was the election).

ss See Wolkinson, The Remedial Efficacy of NLRB Remedies on Joy Silk Cases, 55 Corneli L. Rev. 1, 30-33 (1969).

so Wolkinson notes that this effect is present regardless of the size of the card majority, and is due not only to the degree of employer interference, but also to the union's economic and financial resources. Id. at 19. 
unsuccessful strike. Either alternative gives validity to many of the employer's pre-election arguments about the powerlessness of the union.

Furthermore, the issuance of bargaining orders is not easily squared with the policy of employee free choice, because such orders always override existing employee sentiment. As a result, courts have been hesitant to enforce bargaining orders. ${ }^{57}$ To many management lawyers and professionals, the prospect of prolonged litigation over a bargaining order ending in a victory for management is quite appealing. Thus management advisors who favor the effort to intimidate do not consider the possibility of a bargaining order as reason for altering their styles.

\section{B. Anti-Union Bias of the Board and Courts}

Recent years have seen a number of significant changes in American labor law. The Board and the courts have limited the scope of collective bargaining and reduced the protection afforded by collective agreements. ${ }^{58}$ They have made it almost impossible for employees covered by collective agreements to protest discriminatory employer actions to the Board. ${ }^{58}$ They have reduced the protection afforded by section 7 of the National Labor Relations Act. ${ }^{60}$ They have increased the obligations of unions to nonmembers $^{61}$ and the likelihood that unions will be held liable to their members for actions taken in good faith. ${ }^{62}$ It has become easier for

${ }^{57}$ See Getman \& Goldberg, The Myth of Labor Board Expertise, 39 U. CHI. L. REv. 681,685 (1972). For the further suggestion that the Board should "proceed cautiously in the issuance of bargaining orders," see id. at 698.

s8 See generally Getman, The Courts and Collective Bargaining, 59 CHI.-KENT L. REv. 969 (1983) (discussing increased judicial hostility to collective bargaining).

s9 In United Technologies Corp., 268 N.L.R.B. 557, 560 (1984), the Board held that where a charge under § 8(a)(1) of the NLRA, 29 U.S.C. § 158(a)(1) (1982), alleges conduct which may form the basis for a grievance which is arbitrable under a collective bargaining agreement, the Board must defer to arbitration.

co 29 U.S.C. $§ 157$ (1982). In Meyers Industries, Inc., 268 N.L.R.B. 493, 496-97 (1984), the Board reversed a line of cases which had held that conduct by an individual employee seeking to improve safety conditions in the workplace was "concerted" and therefore protected under $\S 7$.

${ }^{61}$ In Hudson v. Chicago Teachers Union Local 1, 743 F.2d 1187, 1196 (7th Cir. 1984), the court held that nonmembers required to pay agency fees to a union as a condition of employment were entitled to elaborate procedural safeguards of their first amendment right not to have their fees spent by the union for the support of political or ideological causes. The court suggested in dicta that an internal union remedy combined with arbitration would be constitutionally inadequate. Id. at 1194-96.

62 For example, in Smith v. Hussmann Refrigerator Co., 619 F.2d 1229 (8th Cir. 1980), a union represented four employees it claimed were entitled to a posted position on the basis of seniority. The collective bargaining agreement contained a modified seniority sys- 
employers to transfer work or terminate jobs in response to union activity. ${ }^{63}$ The reach of the restrictive secondary boycott provisions has been expanded, and the Supreme Court has specifically announced that the first amendment right of unions to enlist the support of other employees and customers is entitled to a lower level of constitutional protection than are the rights of other groups seeking social change. ${ }^{64}$

That these developments reflect an anti-union trend seems to me obvious. This trend has been widely noted.$^{65}$ It is less obvious that this trend draws considerable strength from the over-regulation of employer speech. Yet in several areas the connection seems so clear that any realistic hope for change in a direction favorable to unions would require a corresponding change in the regulation of employer campaign tactics.

1. Regulation of Union Campaign Tactics. The courts have often imposed foolish restrictions on union campaign tactics. For example, in NLRB v. Savair Manufacturing Co., ${ }^{66}$ the Supreme Court solemnly declared that employees might be coerced into voting for representation if unions could waive dues and initiation fees for those employees who signed authorization cards during the campaign. ${ }^{67}$ The Court justified its conclusion by reference to its earlier decision in NLRB v. Exchange Parts Co., ${ }^{68}$ which had denied employers the right to make or promise benefits during a campaign, quoting its statement there that employees were "not likely to miss the inference that the source of benefits now conferred is also the source from which future benefits must flow and

tem, in which seniority was to govern certain job transfers only where skill and ability were substantially equal. The court held that because the union had failed to satisfy itself that the employees whose case it supported during arbitration were equal in ability to those who had been given the positions, "sufficient evidence existed for the jury to conclude that the union exceeded the permissible range of reasonableness with regard to its representation" of the employees whose qualifications for the opening were merit-based-even though the employer took the position of the "merit" employees in the arbitration proceeding. Id. at 1239.

6s See, e.g., Weather Tamer, Inc. v. NLRB, 676 F.2d 483 (11th Cir. 1982) (reversing due to lack of substantial evidence a decision of the Board that partial plant closing was retaliatory and constituted a violation of $\S 8(a)(3)$ of the NLRA, 29 U.S.C. $\S 158(a)(3)$ (1982)).

ot See infra notes 78-96 and accompanying text; see also Getman, Labor Law and Free Speech: The Curious Policy of Limited Expression, 43 MD. L. REv. 4, 12-19 (1984).

os See Oversight Hearings on the Subject "Has Labor Law Failed": Joint Hearings before the Subcomm. on Labor-Management Relations of the House Comm. on Education and Labor and the Subcomm. on Manpower and Housing of the House Comm. on Government Operations, 98th Cong., 2d Sess. (1984), and materials cited therein.

o6 414 U.S. 270 (1973).

${ }^{67}$ Id. at $277-78,281$.

68 375 U.S. 405 (1964). 
which may dry up if it is not obliged." ployees who receive or are promised benefits respond as though they have been threatened makes little sense as applied to employers, and none as applied to unions. ${ }^{70}$ But the reference to $E x$ change Parts makes clear that the Court was motivated by the desire to be even-handed in its treatment of unions and employers. The same patronizing vision of employees as easily manipulated informs the approach to both. Similarly, during the periods in which the Board has regulated campaign representations, the courts have been zealous in insisting that union statements concerning gains achieved at other facilities be stated with precision. ${ }^{{ }^{1}}$

As the earlier discussion shows, the loss of one or another stock campaign statement will have little effect on the success of union organizing. Nonetheless, regulation of campaign tactics leads in many instances to the overturning of elections, and it must be understood that overturning a union victory is a more serious matter than is overturning an employer victory. In the latter case, the company continues to operate free of the union-the same result as the election would have provided-until a new election is held and the union is victorious. In the former, however, employees who voted for the union are denied representation. Thus, a rule which was purportedly created to insure even-handedness has in reality worked against unions.

2. The Issue of Access. Employers have easy and instant access to their employees during an organizing campaign. Although the Supreme Court recognized quite early that the right to consider the pros and cons of organization is included under section 7 of the NLRA, unions do not have a comparable opportunity to state the case for representation, and the trend of the law is toward limiting their opportunities still further. The two leading cases dealing with union access are NLRB v. Babcock \& Wilcox $\mathrm{Co}^{72}$ and NLRB v. United Steelworkers of America (NuTone, Inc.). ${ }^{73}$ In Babcock \& Wilcox, the Court held that an employer could normally "post his property against nonemployee[s]," which

${ }^{69}$ Id. at 409, quoted in Savair, 414 U.S. at 280.

70 See, e.g., Savair, 414 U.S. at 285 (White, J., dissenting) ("the union glove is not very velvet" and "in the union context, the fist is missing").

7 See Getman \& Goldberg, The Behavioral Assumptions Underlying NLRB Regulation of Campaign Misrepresentations: An Empirical Evaluation (pt. 2), 28 STAN. L. REv. 263, 264-65 (1976) (discussing treatment of misieading union statements about benefits secured in other bargaining units).

${ }^{72} 351$ U.S. 105 (1955).

${ }^{73} 357$ U.S. 357 (1958). 
meant that professional union organizers could be kept off the premises. ${ }^{74}$ In NuTone, the Court held that employers who engage in anti-union solicitation are not thereby required to permit unions to solicit on the premises. ${ }^{75}$ While the Court in both cases recognized the propriety of granting the union greater access if the Board found a significant imbalance in informational opportunities, ${ }^{76}$ the Board has only rarely exercised this power ${ }^{77}$ Both liberal and conservative Boards have denied union claims for access whenever the union had any possibility of reaching the employees through other means. Even during periods in which the Board has been quite sensitive to the possibility of employer coercion, it has not granted unions greater access to the employees as a means of overcoming the coercive impact deemed to be inherent in the employees' economic dependence upon the employer. They have instead sought to provide protection through the extension of Board doctrines limiting employer campaign statements and tactics. Yet it seems clear that greater access would be a much more effective way to permit unions to overcome whatever coercive advantage the employer obtains from its position. It makes far more sense to permit unions to make an immediate response to employer threats than for the Board to respond by setting aside an election or issuing a bargaining order long after the election has been held or postponed.

Even apart from the need to offset the impact of employer coercion, greater access would be an extremely important right for all unions. Data indicate that familiarity with the union's case is positively correlated with voting for the union. ${ }^{78}$ Moreover, the very fact of union access would be an effective message to the employees that the law has the power to grant unions a significant role despite employer opposition. Direct access would give the employees a more realistic appreciation of what selecting the union would mean. The missing ingredient of free choice is most likely to be a sense of the particular union involved in the campaign: its representatives, its arguments, and its record. It seems obvious that employees who know the employer but are doubtful about the union ought to be given the chance to learn about the union at first hand.

74351 U.S. at 112.

75357 U.S. at $362-63$.

${ }^{76}$ See Babcock \& Wilcox, 351 U.S. at 112; NuTone, 357 U.S. at 363-64.

77 See Note, Property Rights and Job Security: Workplace Solicitation by Non-Employee Organizers, 94 YALE L.J. 374, 382 n.46 (1984).

78 See LaW \& REALITY, supra note 7, at 104-07. 
It is thus remarkable how little Board or judicial concern has been directed to the issue of greater union access.

The law relating to access is generally explained in terms of the courts' protectiveness of property rights. But this cannot be the entire story. ${ }^{79}$ Behind the law's almost total unwillingness to grant access must rest an unstated quid pro quo: since campaign regulation prevents employers from stating their most effective arguments, it is fair to require unions to scramble to get their messages heard.

Every union organizer to whom I have put the question acknowledges that this is a poor trade. When I interviewed Vicki Saporta, Director of Organizing for the Teamsters, she politely but firmly accused me of understating the potency of employer coercion. But when I asked her if she would be willing to give up Board regulation of employer speech in return for equal access, she did not hesitate for a moment before answering in the affirmative..$^{80}$ Her response was the same as that of every other major figure in union organizing to whom I have put the question. Yet the theme of employer coercion is constantly struck by unions and their academic supporters while the claim for equal access is rarely made. ${ }^{81}$

3. Union Free Speech Claims. In NLRB v. Retail Store Employees Local 1001 (Safeco Title Insurance Co. . $^{82}$ and in International Longshoremen's Association v. Allied International, Inc., ${ }^{83}$ the Supreme Court extended the reach of the secondary boycott provisions of the NLRA. ${ }^{84}$ Safeco prohibited a peaceful picketing effort aimed at convincing consumers not to purchase a particular product, ${ }^{85}$ and Allied prohibited a boycott aimed at protesting

78 Courts have recently shown a willingness to recognize that employees have a property interest in their jobs, and thus may only be discharged for cause. To the extent that employees are drawn to unions out of concern for job security, courts should recognize that union organizing at least presents a case of conficting property rights. See Note, supra note 77 , at 391-92.

${ }^{80}$ Interview with Vicki Saporta, New Haven, Conn. (Spring 1985) (transcript on file with author).

s1 It is noteworthy that Professor Weiler's important article on union organizing, which deals extensively with the question of intimidation, does not even deal with the issue of access. See Weiler, supra note 50.

82447 U.S. 607 (1980).

ss 456 U.S. 212 (1982).

84 National Labor Relations Act, § 8(b)(4), 29 U.S.C. § 158(b)(4) (1982).

${ }^{88}$ The Court distinguished NLRB v. Fruit Packers (Tree Fruits), 377 U.S. 58 (1964), which permitted product picketing, on the grounds that the picketing in Safeco was directed against the only product sold by the neutral retailer. The Court held that such picketing had the same effect as an unlawful secondary boycott, Safeco, 447 U.S. at 612, and was therefore not protected by the first amendment, id. at 616 . 
Russian involvement in Afghanistan. ${ }^{86}$ In both decisions the Court quickly dismissed the unions' claims that their activity was protected by the first amendment. ${ }^{87}$ Subsequently, the Court held in NAACP v. Claiborne Hardware $\mathrm{Co}^{88}$ that civil rights boycotts and appeals to customers were constitutionally protected. In its opinion the court distinguished its earlier labor decisions on the grounds that such cases involved economic regulation" and not the "peaceful political activity" which " "has always rested on the highest rung of the hierarchy of First Amendment values." "90

It is difficult to understand how the cause of labor, a cause which has been in the forefront of agitation for social change, which has united millions, and which has had massive political consequences for the most important national and international issues of our times, can be relegated to a special category of limited first amendment protection because it is not "political." It seems obvious that this approach is made far easier by the comparable restriction upon first amendment rights of employers which the Court permitted in NLRB v. Gissel Packing Co. ${ }^{91}$ In that case the Court limited employers' first amendment right to discuss the harmful effects of unionization to discussion of those "precise effects" of unionization that are "demonstrably probable consequences beyond [the employer's] control."92 The decision was justified on the grounds that because of their economic dependence upon the employer, employees are particularly prone to influence by nuances of coercion in employer speech. The Court did not rely on Gissel in its treatment of union picketing and boycotts. At the very least, however, both areas are infected by similar stereotypical and paternalistic visions of workers as people whose decisions are not made on the basis of ideas but on the basis of fear and coercion.

The Court in Claiborne Hardware referred to " the delicate balance" " of regulation under the National Labor Relations Act. ${ }^{\text {s3 }}$

${ }^{88}$ The Supreme Court agreed with the appellate court below that secondary boycotts are particularly objectionable when they are "in aid of a random political objective far removed from what has traditionally been thought to be the realm of legitimate union activity." " 456 U.S. at 225-26 (quoting 640 F.2d 1368, 1378 (1st Cir. 1981)).

s7 See Safeco, 447 U.S. at 616; Allied, 456 U.S. at 226.

8s 458 U.S. 886 (1982).

so Id. at 912 .

so Id. at 913 (quoting Carey v. Brown, 447 U.S. 455, 467 (1980)).

91395 U.S. 575 (1969).

92 Id. at 618.

${ }^{23} 458$ U.S. at 912 (quoting Safeco, 447 U.S. at 617 (Blackmun, J., concurring)) (discussing rights of neutrals). 
Implicit in the use of the term "balance" in labor law is the idea that the regulation is permissible because it falls neutrally and evenly on both labor and management. The current balance of first amendment restrictions, however, is unfavorable to unions. There is little value to the labor movement in forcing employers to use slightly more roundabout ways of delivering the message that the advent of the union could lead to harmful consequences for the employees, ${ }^{94}$ but there is considerable cost to labor in not being able to picket peacefully to enlist the support of other workers and customers. ${ }^{95}$

The Court's effort to contrast union appeals and "legitimate" political speech is particularly disturbing to unions like HERE that seek to make their case in unconventional ways and through appeals to varying constituencies. The reason most seasoned observers expected the strike of the Yale clerical workers to fail was that the union was not in a position to shut down the enterprise or inflict substantial economic harm on the university through the withholding of services. The strategy which the union developed was to embarrass Yale and threaten its standing with important constituencies in the local community and the nation. It hoped ultimately to demonstrate that it was the union which stood for the values of social progress, fairness, and individual excellence with which Yale is often associated. ${ }^{96}$ To achieve its purpose, the union called mass rallies, held candlelight vigils, and engaged in acts of civil disobedience. It brought to campus various civil rights and feminist leaders. ${ }^{97}$ Its purposes in using those tactics were not only to attract publicity but to associate itself with the civil rights movement, the early days of unionism, and the independent black trade union movement in South Africa (which frequently employs silent candlelight witnessing). A main thrust of the union's campaign was to attack both conscious and unconscious sexist elements in Yale's policies. The campus was filled with buttons bearing a legend of "59 cents" with a line through it. The union

3ee LAw \& REALITY, supra note 7, at 159-60.

${ }^{9}$ See Note, Labor Picketing and Commercial Speech: Free Enterprise Values in the Doctrine of Free Speech, 91 YALE L.J. 938 (1982).

${ }^{83}$ Interview with John Wilhelm at Yale University (Spring 1985) (transcript on file with author). The importance of Yale's reputation is illustrated, perhaps ironically, by the fact that Andrea Ross took a job at Yale "with the misguided notion that it was a liberal, humanitarian institution." Interview with Andrea Ross at Yale University (Spring 1985) (transcript on file with author).

${ }_{97}$ The group included Ralph Abernathy, Cesar Chavez, Judy Goldsmith, and Eleanor Smeal. See Ladd-Taylor, supra note 40. 
brought in feminist speakers, civil rights leaders, and other social activists. It publicized a faculty report which demonstrated that women and minority employees were bunched towards the bottom of the employment ladder. The union conducted a teach-in during which the educational impact of its proposals was discussed. In various direct and subtle ways, the union allied itself with local town sentiment that saw Yale as arrogant and elitist.

The messages which the union sought to convey through these tactics were: (1) that the labor movement is part of the civil rights movement throughout the world, committed to promoting the cause of the disadvantaged and aiding victims of discrimination; (2) that even enlightened liberal institutions like Yale have discriminated against women and minority employees; (3) that the cause of education did not justify poor wages and benefits for the clerical and technical workers who make a major but unappreciated contribution to the program; (4) that elite universities do not adequately respect people who do not have academic credentials; and (5) that justice demands that those who do the routine and technical work of such an institution be given a greater share of its income. These are messages directed to the basic organization of society. Their political content seems obvious and was apparent to all of us who experienced the strike.

When one argues that certain groups are entitled to greater economic benefits because they have been discriminated against in the past, the line between economic and political claims becomes meaningless. Otherwise the actions of the NAACP that were involved in Claiborne Hardware would have to be classified as economic. If there is a difference between the first amendment rights of HERE and of the NAACP, it is because the Court chooses to view labor relations as a special (and weaker) case for first amendment purposes.

The suggestion that labor relations is an area in which the exchange of ideas is not valuable enough to justify the risks seems to be based on a vision of working people as easily cowed, overly emotional, and likely to respond without thought to both union and employer solicitations. This vision, often found in law but rarely substantiated by reality, demeans and patronizes workers.

\section{CONCLUSION}

It is difficult to measure the extent to which union organizing has been negatively affected by the labor movement's willingness to blame its defeats upon employer coercion. In my discussions with union organizers before and after particular elections and in 
discussing the issue of organizing generally with union officials, I have been struck by how often they attribute their failures to this cause. Attempting to deal with employer coercion has diverted energy and attention which might better have been directed to a more realistic appraisal of union losses and to the development of techniques to overcome them.

Vincent Sirabella recently stated at a conference that

repetitive opinions have been offered for this dramatic deterioration in our ability to organize the unorganized. Generally the opinions focus on the employer bias of the NLRB, the anti-union national administration, the surge of union-busting consultants, [and] the need for labor law reform . . . . I submit that these rationales are at best, peripheral causes for our increasing stagnation. . . . We are confronted with this giant puzzle because the labor movement permitted a generation of time to elapse, approximately (1955-1980), without preparing, by education and training, for this current generation of organizers. $^{98}$

The concern with coercion has also led unions to adopt selfdefeating organizing tactics. For example, unions concerned about coercion are apt to keep their campaigns secret for too long and to avoid asking all but their most vocal supporters to identify themselves as members. This prevents the type of dynamic that can occur when, as happened at Yale, more and more people come to the fore. At one point in the Yale election campaign, for example, the union printed a poster that resembled the Declaration of Independence and included the signatures of hundreds of union supporters. Many of the employees have since reported to me how exhilarating an experience it was to see their names and that of so many of their co-workers publicly listed together on such a document.

In his talk on union organizing Sirabella also compared the typical union organizer to "a boxer who telegraphs every punch." He argued that the way to fight union-busting consultants was to "develop strategies which are unpredictable and unorthodox." Pointing out that in the past many unions had organized without any legal protection, he concluded that "labor law reform would be meaningless to any union that failed to restructure its methods of organizing with careful recruitment of organizers, [and] first class

\footnotetext{
V. Sirabella, supra note 3 , at 3 .

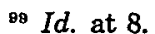

${ }_{100}$ Id.
} 
training."101

Sirabella is aware that talented and committed people are available both inside and outside the ranks of organized labor. $\mathrm{He}$ has recruited and trained the likes of John Wilhelm, ${ }^{102}$ Karl Lechow, ${ }^{103}$ and Andrea Ross. ${ }^{104}$ The impact has been dramatic and positive. It need not remain an isolated success amidst general failure. If the labor movement will seek out, train, and support the best people available to it, it will be able to organize successfully despite the Board and the courts. If it does not it will continue to dwindle.

$101 \mathrm{Id}$. at 10.

102 John Wilhelm is currently Business Agent for Local 34 and New England Vice President of HERE. He has become a nationally recognized labor leader. He comes from a prominent Virginia family. $\mathrm{He}$ is a Yale graduate whom Vinnie recruited through an advertisement in the New Haven paper seeking someone "willing to work long hours for low pay" to learn to be a labor leader.

${ }^{103}$ Karl Lechow is a college graduate who comes from an immigrant family of committed radicals and union organizers. He is currently Deputy Director of Organizing for HERE. $\mathrm{He}$ is a fiery, class-conscious organizer whom both John and Vinnie describe as the best in the union.

104 Andrea Ross comes from South Africa. She first realized the potential of unions to break through barriers of class and race when she worked as a secretary for a labor institute there. She worked as a clerical employee at Yale until she was brought to the fore during the Yale organizing drive. She served on the organizing and negotiating committees. She is currently on the professional staff of Local 34 . 